\title{
Promotion of Entrepreneurship in West-Africa, Lessons from China (Part II) - Case: Cloth Product Innovation in the Schools and Colleges of Benin
}

\author{
Rodrigue Againglo and Jun Shan Gao
}

\begin{abstract}
Nowadays the world is in a perpetual progress and everyone should unconditionally readjust his own step in order to be in a dynamic market competition. Nobody wants to loose opportunity. Then, we found that it is time to change the old habit of dressing in schools of Benin. Education environment is very sensible not only for the parents but also for the youth scholars. Since almost a century our Benin schools provide tee-shirts to its students for physical education sport purpose. Most of people, our grand-parents wore that, we wore that and till now students keep using the same shirts. We find this very old and would like to go through a peaceful revolution by introducing new products that show good looking of the scholars. When we find the soccer players on the air ground with their own jerseys, it looks smart and attractive, shows and expresses the unity and characteristic of a team heart, team work. We try to get that vision of things to introduce into the school environments of new products. We believe this work will help to improve the country's economy growth, employments rate and contribute positively to the social well-being of that Country.
\end{abstract}

Index Terms-Entrepreneurship, product innovation, career choice, job opportunity, promotion, physical education.

\section{BACKGROUND}

Entrepreneurship is a business management concept that can be easy to understand in terms of languages used long time ago. It takes into account motivation, innovation and money investment. Entrepreneur has to assume the risk in the business, organize and manage it in order to guarantee the return or improve on the capital employed. Entrepreneurs do not arrange capital because it could be beyond their capacity. However, successful entrepreneurs in the past have been able to convince the venture capitalists that their idea and business practices are sound and that they get in a partnership, proper returns on the money can be gained. Marco Polo was historically one of the first entrepreneurs. He traded with Asia in the 13th century and was confident of how he could succeed. His ideas were financed in Venice by venture capitalists with who he would share his profits. These loose associations go through Europe and other parts of the world. Then, people with money were willing to back ideas and schemes when they notice their profits in such entrepreneurship activities.

Cantillon, the economist, in the 17 th century, opined that an entrepreneur was a risk taker. In the 18 th century, an en-

Manuscript received November 9, 2016; revised December 19, 2016.

The authors are with University of Science and Technology Beijing, Beijing Haidian District 30 Institute Road 100083, (USTB), China (e-mail: 1196928602@qq.com). trepreneur was someone who can ran huge production projects without any financial risk and with finance, support provided by others, the government. A clear distinction was made between the entrepreneur and the provider of capital. Even Thomas Edison ran into a huge financial crunch when he wanted to support his ideas, his inventions and had to get through capital from private sources. That was a complete entrepreneur and left the financial support of his venture to others.

Entrepreneur is one who is willing to take the risk to engage in self-employment. The forms of engagement can vary from survival to growth-oriented activities [1].

Drucker's book on innovation and entrepreneurship championed "specifically entrepreneurial" strategies that he described as important, distinct and different. They were aimed at breaking down the barriers to change that often discouraged CEOs [2].

What is innovation?

Drucker opined innovation as the tool or instrument used by entrepreneurs to exploit change as an opportunity whereas Byrd and Brown viewed as an equation model $($ Innovation $=$ Creativity + Risk-Taking $)[3]$.

\section{A. Development of Entrepreneurship in the World}

The present development of entrepreneurship started in 1950"'s after the World War II when nations were looking to rebuild up their economies from the ravages of the war. People had new ideas for jobs as individuals and started in small ways with limited capital to form businesses which went on to challenge the well established companies.

The Internet led to a virtual explosion of new ventures, and entrepreneurs who have found newer ways to do business are taking advantage of the ease of communication.

Nowadays, an entrepreneur is regarded as one who organizes, controls, purchases raw materials, arranges materials and machinery to produce the goods. An entrepreneur is also one who throws in their own expertise and inventiveness and also administers the venture.

\section{B. Career Choice of Entrepreneurs}

There are a number of benefits from the promotion of youth entrepreneurship or self-employment that are commonly discussed by commentators. An increased in the number of self-employed as percentage of population $(9.9 \%$ in 1981 to $15 \%$ in 1991). People feel more satisfied in selfemployment [4], [5].

Oswald and Blanchflower found the values that make someone entrepreneur - environmental factors [6]; family background (fathers career ; inheritance); education ( not important, start at early age; work experience ( very 
important ); action factors (activities entrepreneur does); are creative and innovative; sport and exploit opportunities; find resource to exploit opportunities; manage risk, create capital; are good net workers, determined.

All over the world entrepreneurship is linked to employment generation, innovation and economic growth, but entrepreneurship has been downplayed in Africa over the past 30 years[7], risk taking personalities can be created through targeted support and development that communicate the reality that, risk and uncertainty are 'perennial facts of life'[8].

Many experts believe that entrepreneurs solve social \& psychological problems (delinquency...) bring back the alienated and marginalized youth into the economic mainstream [9]. There is a direct effect on employment if new young entrepreneurs hire fellow youth. Lazear tested human capital investment approach by analyzing students and found that those who follow a broader course selection tend to be more entrepreneurial that those specialized [10]. The dominant forms of entrepreneurial activity in SubSahara are Small and Medium-sized Enterprises. They act as incubators of specialization and innovation within an economy, allowing the country to diversify and industrialize [11]

Researchers have just only started to explore the critical entrepreneurial question as to what factors contribute to the existence of entrepreneurial opportunities [12]. It refers to how market failure may be used to explore source of opportunities through environmental area. If that is exploited it has the potential to not only generate entrepreneurial rent, but also reduce the market imperfection and improve in the global environmental conditions.

\section{Success of Young African Entrepreneurs}

\section{1) Farmer and teacher in Senegal}

Fonio, a highly nutritious cereal, grows in sixteen African countries. It is one of the easiest crops to cultivate growing under most soil and weather conditions. The husking of fonio is time-consuming and labor intensive, working ultimately against the popularity of the cereal. For reducing the amount of time it takes to husk fonio by hand, he invented a machine in 1993 that removes the husks in a few time. Since then, the machine has undergone extensive field trials and is now manufactured in Africa (Dakar and operating throughout West Africa). In regions where the machines are in use, farmers are planting more of the cereal. "More than twenty (20) machines are now operating in seven (7) West African countries," said the author, who is seeking for financing aid to set up a factory for large-scale production. Fonio also offers a potential source of foreign. A Young age farmer (Lesotho) An Entrepreneur from a young age, started a catering business at the age of fifteen while studying marketing, before moving into waste recycling. In 2010, the young farmer switched businesses again into poultry and piggery, starting with five hundreds (500) layers and six (6) pigs. Business flourished within five (5) months to over ninety (90) pigs and he employed six young people to help run his expanding business. To date, the business is thriving despite volatile market conditions, growing to over five thousands (5000) layers and now expanding once again into the petroleum sector. As a member of the Lesotho National Farmers Union and Basotho Poultry Farmers Association (BAPOFA), he hosts young people in his farm for experiential training, gives tours of his farm to school children and shares his experience in farming. Using his training in marketing to his advantage, he has also taken to the media to share his work and inspire other young people to take up farming in order to feed the Lesotho nation.

\section{Procedure AND Data Collection Methods}

There are two contexts here - the problem context and the approach context. A literature review will be a valid part, as it is a necessary step in the structure of a research and forms integral part of any research conducted.

Through the entrepreneurs in educational scope, there is an issue of interviews that help more in the part of analysis and development of the topic as well. We proceed with discussions to the headmasters and school promoters to collect more data from samples. The expected people were two hundreds (150), but a hundred were randomly targeted. The following questions are the field of interviews, very useful in terms of market research.

Questions of interview

1) How many students are in your school?

2) Do you have interest in the new products? Why?

3) How many would you like to order?

4) Would you mind to change the supplier in case of non-satisfaction? Why?

5) What are your suggestions about this project?

6) Do you agree with the quotation of the products?

7) what are the student intentions?

\section{ENTREPRENEURIAL ACTIVITY IN PHYSICAL EDUCATION MARKET}

\section{A. Modernization of Dressing Habits in the Schools of West-Africa}

Nowadays the world is in a perpetual progress and everyone should unconditionally readjust his own step in order to be in a dynamic market competition. Nobody wants to loose opportunity. Then, we found that it is to change the old habit of clothing in schools of Benin. Education environment is very sensible and this is due to the youth scholars. Since almost a century our Benin schools used the habits of wearing tee-shirts by students to go for physical education (Figure: 1). Most of the people even our grand-parents also wore that, we wore that and till to now students keep wearing the same shirt. We find this very old and would like to go for a revolution through new looks of students in the field. When we find the soccer players on the ground with their own jerseys, it looks smart and attractive it shows and expresses the unity and characteristic of a team heart, team work. We try to get that vision of things to introduce in the school environment new products

\section{B. Physical Education Jersey Product}

The tee-shirt of every student in the schools of Benin will be changed to a couple of jersey. During the physical education classes in the schools, students will appear in their new looks (see Fig. 2). Personalized jerseys with name, logo and 
contact information of the schools are the innovative and creative field of interest of the youth.

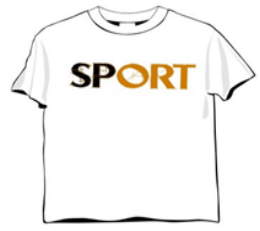

Fig. 1. Old product

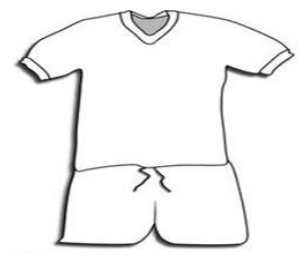

Fig. 2. New product

\section{Personalized Scholars Clothing}

Students are motivated and feel good, and comfortable in their new looks. They feel proud and are excited to go to school. Providing clothes with name, logo and information of a school already existed in the private schools in Africa, the public one may be our market attraction .But the main reason why we introduce them again concerns the manufacturing that we will explain more in the development of the topic.

\section{Place of Manufacturing Products}

Our product is essentially made in China for various reasons.

Export rebates (discount) on Chinese products are the main reason why goods exported from the mainland are cheaper abroad. China already has a comparative advantage in processing and assembling products, but on top of that it grants tax rebates on those that are exported to promote economic growth and solve the unemployment problem.

It is this policy that has become the source of extra profit for many foreign companies. Given the intense competition in the global market, this policy is also lowering the profit of Chinese exporters.

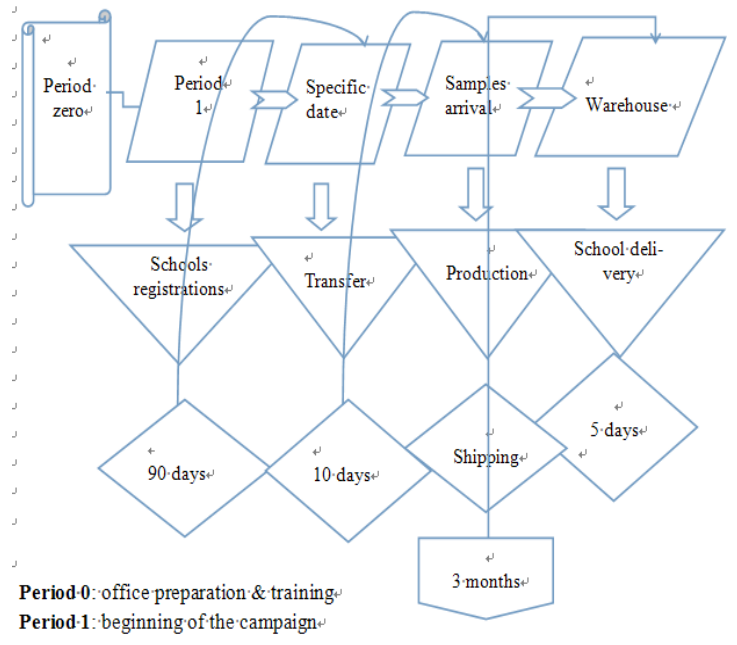

Fig. 3. Processing model.

\section{E. Description of the Process}

The project is based on a team work that will go to the colleges and schools in Africa to hand the dialogue with the promoters that are essentially in a private sector of educations. After receiving the admission of the schools from the campaign of a specific year, the promoters should make their choices and requirements as far as their jerseys designs are concerned, and the schools registrations will last for ninety (90) days. After that we discuss the issue of deposit and transfer that will last for ten days almost.The team takes note and sends the requirement to China factory. There are some samples that will be made and send to Africa by the manufacturer. After the promoter approves the samples, the factory in China will start to produce the jerseys. Once it is over we go to the shipping process- samples arriving, productions and shipping, this may last for three months. We plan to get the products in Africa earlier, the sooner, the better. The next step is to deliver the products from the warehouse to the schools within five days (see Fig. 3), everything depends on the quantity.

\section{F. Result on the Surveyed Questions}

\section{1) How many students are in your school?}

According to the promoter of each school, the scholar population is different from one school to another. In effect it depends on the statue of that school - it may be private or public. The population is between five hundreds (500) and one thousands five hundreds (1500) students. Example of schools "Saint Romaric; CS Adetro; La Plenitude";

Two semesters in an academic year and the numbers of students can change after each semester. Schools start sometimes with physical education during the first or the second semesters, it depends on the schools policy management.

2) Do you have interest in the new products? / Would you mind to change the supplier in case of non-satisfaction?

Why?

After introducing demonstrating the importance of the new products, promoters are interesting and motivated. Think about the business environment this project provides and the built of interest toward their schools whether it profitable assume the real motivations. First of all schools promoters are excited and accept the new products.

The main subject is about trust, as the environment is in a perpetual communication with new technologies and information system, social network, people trust you unless you convince them through your logical theory. So the theory has to be explained and demonstrated to come up with the expected reactions from promoters. As Fry and Hattwick said, we focus on the environment of business and work together with everyone because businesses are neither independent nor completely isolated from the internal and external environment within which they function [13].

3) What are the student intentions / how many does each school orders?

Through a kind of advertisement the students got the information and are very excited. They reacted in a positive way and were looking forward to being relooked as the soccer stars, basketball or volleyball stars. Most asked about the exactitude of the date of that new products arrival. Schools officers made the schools choice and explained about the products. Motivation and trust occurs in the hearts of the students

4) Do you agree with the quotation of the products? What is your contractual method of payment?

That is a hard work in the process of registration. We surveyed many schools, in each one we contact the staff members, the promoters and get in touch with the students. For the new products, ninety percent of those schools (Fig. 4) are excited and given they intention of commands (give the 
quantity and the color of the product desired, then have accepted to cooperate immediately). This is a real motivation in the project that shows a very nice future for the business development.
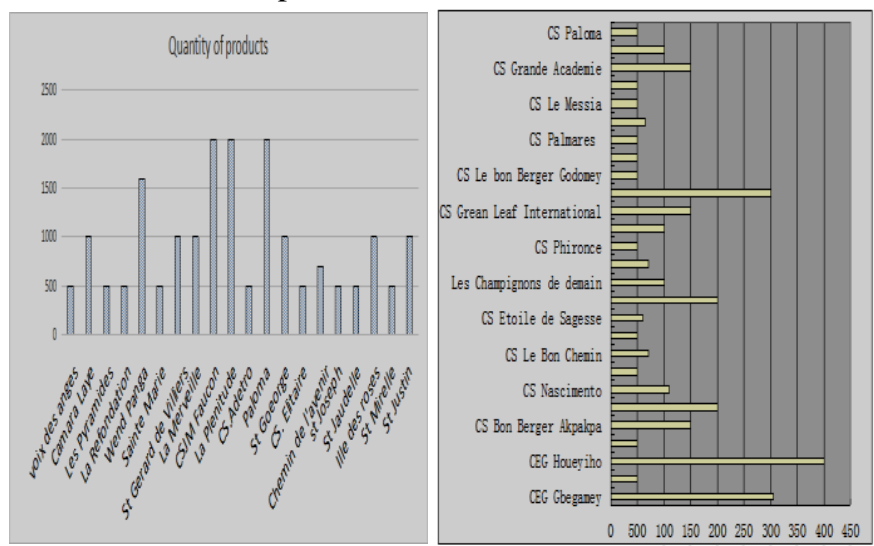

Fig. 4. 2015 and 2016 Surveyed schools.

\section{ORGANIZATIONAL STRUCTURE}

Organizational structure is a system used to define a hierarchy within an organization. It identifies each job, its function and where it reports to within the organization. This structure is developed to establish how an organization operates and assists an organization in obtaining its goals to allow for future growth. The structure is illustrated using an organizational chart.

The highest ranking member of an organizational chart is one or several top executives referred to as the president, chief executive officer or chief operating officer. For this case study CEO is the highest position (General Manager; Vice-Manager; General Coordinator, Marketing Manager, Accounting Manager).

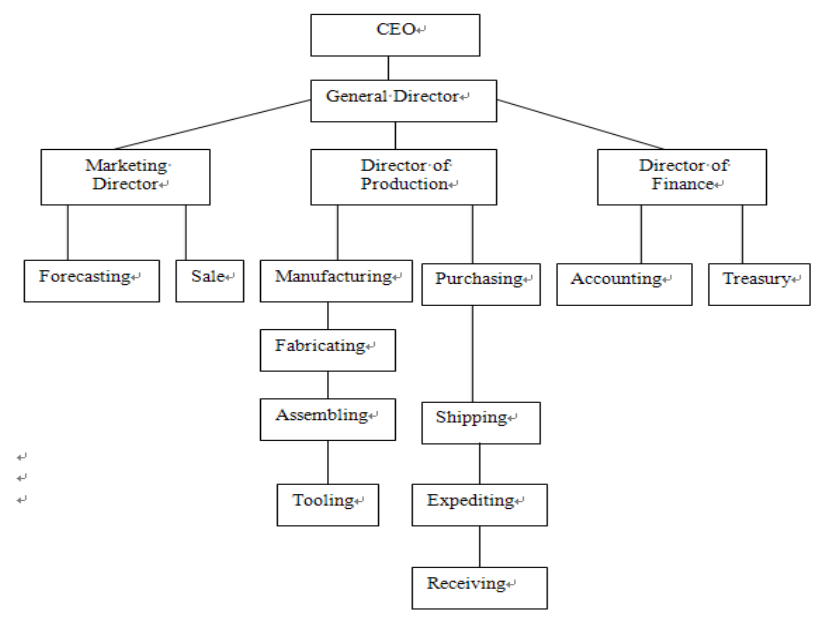

Fig. 5. Organizational structure model.

\section{A. Job Descriptions}

When an organizational structure is designed, job descriptions may be developed. It may not only meet an organizations goals, but also allow for organizational and employees growth. Recruitment is one of the highest investments for organizations. Organizational structure is also a basic core to create salary structures. The present case study provides different post such as a CEO, General Manager; Marketing Manager; Production Manager; Financial Manager; Secretariat Agent, a Commercial leader and twenty-five (25) Commercial Agents for one region over seventy seven in the Republic of Benin (see Fig. 5). The job opportunity is available to satisfy a few part of the young degree holders.

\section{B. Expansion}

If an enterprise expands, the organizational structure provides a concession for growth. This may include adding additional new divisions, expanding several functional areas or appointing additional executives. When the structure is reorganized for expansion, it provides the basic foundation to edit salaries and job descriptions efficiently with a minimum disruption to an organization's operation.

Employment flexibility has been advocated as a mean of ensuring the full and efficient use of human resources [14][16] (Capelli, 1999, Handy, 1989; Lepak \& Snell, 1999). The need of new personals recruitments expresses the development and the well-being of the state of that company (see Table I). This is the case of the present framework.

\begin{tabular}{|c|c|c|c|}
\hline No & $\begin{array}{c}\text { Post/one } \\
\text { Town }\end{array}$ & $\begin{array}{c}\text { Job oppor- } \\
\text { tunity/Town }\end{array}$ & $\begin{array}{c}\text { Job opportuni- } \\
\text { ty/77 Towns of } \\
\text { Benin } \\
\end{array}$ \\
\hline 1 & CEO & 1 & 1 \\
\hline 2 & $\begin{array}{c}\text { General } \\
\text { Manager }\end{array}$ & 1 & 1 \\
\hline 3 & $\begin{array}{c}\text { Vice-General } \\
\text { Manager }\end{array}$ & 1 & 1 \\
\hline 4 & $\begin{array}{c}\text { Marketing } \\
\text { Manager }\end{array}$ & 1 & 77 \\
\hline 5 & $\begin{array}{l}\text { Production } \\
\text { Manager }\end{array}$ & 1 & 77 \\
\hline 6 & $\begin{array}{l}\text { Finance } \\
\text { Manager }\end{array}$ & 1 & 77 \\
\hline 7 & $\begin{array}{c}\text { Secretary } \\
\text { Agent }\end{array}$ & 1 & 77 \\
\hline 8 & $\begin{array}{c}\text { Commercial } \\
\text { Leader }\end{array}$ & 1 & 77 \\
\hline 9 & $\begin{array}{c}\text { Commercial } \\
\text { Agents }\end{array}$ & 25 & 1925 \\
\hline Total & & 33 & 2314 \\
\hline
\end{tabular}

\section{LIMITATIONS ON THIS STUDY}

There exist a limitation in this study, mainly constraints may be the financial and distance as well, because in Africa (Guinea, Togo; Ghana ...they are not too close to each other), so we often base on the internet and others tools of communications like phone, post office.....

Major limitation may derive from the use sampling in selecting the important personality of the schools that are sometimes unavailable. Anyway an effort will be done to conduct this research using the resources available.

\section{CONCLUSION}

With this study we hope to contribute to the knowledge base and help to satisfy interested people, no matter they are in quest of advises or theories that can solve their problem, we would hopefully have an approach of solutions toward the topic in order to reinforce and remote the faith, the confidence, provide useful information and methods for the society and in the business sectors as well. For the present case study, we can develop and supply other products in that educational business sector, example: Personalized shoes of 
scholars, each student with its own shoes personalized with school name; "personalized book note agenda"

In the classroom for e.g., it is said to take note while teachers are giving details about a specific topic. In this area book note is very useful and convenient to register quick the teacher's explanation. In the personalized book note, we will provide in the first pages some good wishes messagewelcome for the academic year of 2015-2016, a message to the students, and we can also provide some award excellent students pictures of the past year.

Apart all that above, African still has more challenges to set up manufacture factories in that specific area of business. We hope and expect African government helps to achieve that future goal in order to provide more input for the societies.

\section{REFERENCES}

[1] F. Chigunta, J. Schnurr, and D. J. Wilson, "Being 'Real; about youth entrepreneurship in Eastern and Southern Africa implications for adults," Institutions and Sector Structures Working Paper 72, 2005.

[2] F. P. Drucker, Innovation and Entrepreneurship Practice \&Principle, 1985.

[3] J. Byrd and P. L. Brown, The Innovation Equation: Building Creativity and Risk-Taking in Your Organization, 2003.

[4] D. G. Blanchflower and A. J. Oswald, "What make you entrepreneur," Journal of Labor Economics, 1998.

[5] S. White and P. Kenyon, "Enterprise-based youth employment policies, strategies and programs" Initiatives for the Development of Enterprise Action and Strategies, 2000.

[6] E. B. Roberts, An Environment for Entrepreneurs WP\# 3300-91-BPS, June, 1991.

[7] K. Marsden, "African entrepreneurs-pioneers of development," Small Enterprise Development, vol. 3, no. 2, pp. 15-25, 1992.

[8] R. Farley, "Poverty and enterprise: Towards the sixth stage of economic growth," The Review of Black Political Economy, vol. 11, no. 2, pp. 229- 250, 2000.

[9] R. Curtain, Youth and Employment: A Public Policy Perspective; Development Bulletin, August 2001, no. 55, pp. 7-11.
[10] E. P. Lazear, Teacher Incentives Swedish Economic Policy Review, pp. 179-214, 2003.

[11] B. White, The Role of Entrepreneurship and Opportunity in SubSaharan Africa, June 9, 2011.

[12] S. Venkataraman. (1997). The Distinctive Domain of Entrepreneurship Research. Foundations of Entrepreneurship, S. Shane Ed., Edward Elgar Press. [Online]. Available: http://ssrn.com/abstract=1444184

[13] F. L. Fry, C. R. Stoner, and R. E. Hattwick, Business: An Integrative Approach with Student CD and PowerWeb, 2003.

[14] P. Capelli, The New Deal at Work: Managing the Market-Driven Workforce, Boston: Harvard Business School Press, 1999.

[15] C. Handy, The Making of Managers, B.I.M., 1989.

[16] D. P. Lepak and S. A. Snell, "The Human resource architecture: toward a theory of human capital allocation and developement," Academy of Management Review, vol. 24, no. 1, pp. 31-48, 1999.

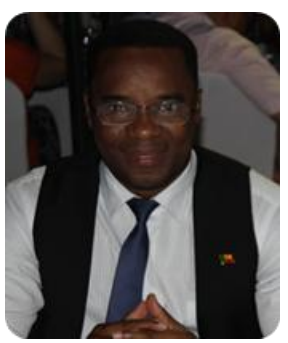

Rodrigue Againglo was born on June 23, 1983 at Abomey (Benin), he received a bachelor degree (with honor) in applied English linguistics in 2008 at the AbomeyCalavi University (UAC-FLASH, Benin).

He received the Confucius Institute Award in 2008 at (UAC). From June 2011, he has been a Specialist in Chinese Language \& Culture, Chongqing Jiaotong University, China. Then he received the master degree in management (MBA), June 2013 at USTB,

China. Since September 2013, he has been a Ph.D. Candidate in enterprise management.

$\mathrm{He}$ is an Author and Co-author of scientific papers \& conferences publications, his research interests are entrepreneurship, enterprise management, employees self-efficacy \& performance, etc.

He was also a Market Research Manager at Ningxia city "Bao tai" Alloys co, Ltd. (China \& Rwanda), in 2014. Actually, he is a Production Manager in "China-Africa Business Center, Benin Cotonou". He is a Manager of "Beka" International Trade Co, Ltd., HKG, China. 